\title{
Chilling and Freezing Temperature Stress Differently Influence Glucosinolates Content in Brassica oleracea var. acephala
}

\author{
Valentina Ljubej ${ }^{1}$, Ivana Radojčić Redovniković ${ }^{2}$, Branka Salopek-Sondi ${ }^{1}$ (D), Ana Smolko ${ }^{1}$, Sanja Roje ${ }^{3}$ \\ and Dunja Šamec $1,4, * \mathbb{D}$ \\ 1 Department of Molecular Biology, Ruđer Bošković Institute, Bijenička cesta 54, 10000 Zagreb, Croatia; \\ kruk.valentina@gmail.com (V.L.); salopek@irb.hr (B.S.-S.); ana.smolko@irb.hr (A.S.) \\ 2 Faculty of Food Technology and Biotechnology, University of Zagreb, Pierottijeva 6, 10000 Zagreb, Croatia; \\ irredovnikovic@pbf.hr \\ 3 Institute of Biological Chemistry, Washington State University, Pullman, WA 99164, USA; sanja@wsu.edu \\ 4 Department of Food Technology, University North, University Center Koprivnica, Trg dr. Žarka Dolinara 1, \\ 48000 Koprivnica, Croatia \\ * Correspondence: dsamec@unin.hr
}

check for updates

Citation: Ljubej, V.; Radojčić

Redovniković, I.; Salopek-Sondi, B.; Smolko, A.; Roje, S.; Šamec, D. Chilling and Freezing Temperature Stress Differently Influence Glucosinolates Content in Brassica oleracea var. acephala. Plants 2021, 10, 1305. https://doi.org/10.3390/ plants10071305

Academic Editors: Abidur Rahman, Balakrishnan Prithiviraj,

Mohammad Aslam and M. Arif Ashraf

Received: 9 June 2021

Accepted: 25 June 2021

Published: 27 June 2021

Publisher's Note: MDPI stays neutral with regard to jurisdictional claims in published maps and institutional affiliations.

Copyright: (c) 2021 by the authors. Licensee MDPI, Basel, Switzerland. This article is an open access article distributed under the terms and conditions of the Creative Commons Attribution (CC BY) license (https:// creativecommons.org/licenses/by/ $4.0 /)$.

\begin{abstract}
Brassica oleracea var. acephala is known to have a strong tolerance to low temperatures, but the protective mechanisms enabling this tolerance are unknown. Simultaneously, this species is rich in health-promoting compounds such as polyphenols, carotenoids, and glucosinolates. We hypothesize that these metabolites play an important role in the ability to adapt to low temperature stress. To test this hypothesis, we exposed plants to chilling $\left(8^{\circ} \mathrm{C}\right)$ and additional freezing $\left(-8{ }^{\circ} \mathrm{C}\right)$ temperatures under controlled laboratory conditions and determined the levels of proline, chlorophylls, carotenoids, polyphenols, and glucosinolates. Compared with that of the control $\left(21^{\circ} \mathrm{C}\right)$, the chilling and freezing temperatures increased the contents of proline, phenolic acids, and flavonoids. Detailed analysis of individual glucosinolates showed that chilling increased the total amount of aliphatic glucosinolates, while freezing increased the total amount of indolic glucosinolates, including the most abundant indolic glucosinolate glucobrassicin. Our data suggest that glucosinolates are involved in protection against low temperature stress. Individual glucosinolate species are likely to be involved in different protective mechanisms because they show different accumulation trends at chilling and freezing temperatures.
\end{abstract}

Keywords: Brassica oleracea var. acephala; low temperature stress; glucosinolates; polyphenols; abiotic stress

\section{Introduction}

Vegetables from the Brassica oleracea subgroup Acephala originated in the Mediterranean region but gained popularity worldwide [1]. This group of vegetables is characterized by leaves that do not form a head. Like other Brassica vegetables, they are considered a functional food due to the scientific evidence linking their consumption to numerous health benefits [2,3]. The health-promoting activities are associated with the presence of glucosinolates, polyphenols, carotenoids, various vitamins, minerals, dietary fibers etc. $[4,5]$. Due to their low caloric value but high content of fiber and phytochemicals, these vegetables are particularly popular among people who want to follow healthy dietary patterns [6].

The popularity of Brassica vegetables from the Acephala group may be related to their strong tolerance to unfavorable environmental conditions, which makes them an excellent crop for cultivation in the current period of climate change [1]. Under increasing environmental stress, the cellular and physiological processes become more and more compromised until limiting conditions for survival are reached. Plants respond to stress conditions with changes in the expression pattern of genes encoding proteins that control 
the biosynthesis of metabolites involved in the interactions between a given plant and its environment. This is an effort by plants to maximize their chances of survival under stress and maintain cellular function by synthesizing basic metabolites required for survival (primary metabolism) and specialized metabolites for specific environmental interactions (specialized metabolism). Specialized metabolites play critical roles in various physiological and pathological processes by participating in biochemical reactions required for proper biological function $[7,8]$.

Our previous studies directly compared the tolerance to drought and salt stress of several Brassica species and showed that kale has the best stress tolerance in the group, correlating with higher levels of specialized metabolites, particularly phenolic compounds [8-11]. Low-temperature stress was also shown to influence specialized metabolism in Brassica plants. For example, flavonoids and anthocyanins were reported to accumulate in response to cold and frost stress in Brassica rapa [12-14], while low temperature stress leads to accumulation of specific flavonol glycosides and hydroxycinnamic acid derivatives in Brassica oleracea var. sabellica [15]. In addition to phenolic compounds, low-temperature regimes may be associated with higher carotenoid accumulation [16]. Glucosinolates play an important role in the abiotic stress response, and their role and that of their degradation products in temperature stress is still under investigation [17].

Plant response to abiotic stress may involve the induction of biosynthesis of various metabolites (polyphenolic compounds, carotenoids, glucosinolates) that are beneficial to human health. Kale (B. oleracea var. acephala) is tolerant to low temperatures, and in culinary practice is considered to have the best organoleptic properties when harvested late in the growth season, after exposure to low temperatures and frost [18]. Study by Steindal et al. [18] showed that cold acclimation of kale increases soluble sugar content, thereby improving taste while decreasing unsaturated fatty acid and glucosinolate contents. Similarly, Jurkow et al. [19] showed that medium $\left(-5.0^{\circ} \mathrm{C}\right)$ and heavy frost $\left(-15.0^{\circ} \mathrm{C}\right)$ increased soluble sugar content, phenolics, and antioxidant activity of kale, which makes harvesting of kale leaves more desirable after exposure to low temperatures.

Considering the excellent cold tolerance of kale and the high content of the abovementioned health-promoting compounds (phenolic compounds, carotenoids, glucosinolates), we first investigated their content in kale under low temperature stress. Then we focused particularly on the analysis of selected indolic and aliphatic glucosinolates. Some previous studies showed that the content of health-promoting compounds may change at low temperatures, but most of these studies were conducted in the field, where other environmental factors are difficult to control. In the present study, we subjected kale to chilling and freezing temperature compared to the control under laboratory conditions where all other parameters expect temperature were constant. In this way, we minimized all other environmental effects that could affect changes in phytochemical levels. In the control plants $\left(21^{\circ} \mathrm{C}\right)$ and plants exposed to chilling $\left(8^{\circ} \mathrm{C}\right)$ and freezing $\left(-8^{\circ} \mathrm{C}\right)$ temperatures, we determined the levels of proline, polyphenolic compounds, carotenoids, chlorophylls, and total and individual glucosinolates to investigate their involvement in the response of kale to low temperature.

\section{Results}

\subsection{Proline Content}

Change in proline content in kale plants exposed to low temperatures is shown in Figure 1. The proline content in control samples was $5.40 \pm 0.30 \mu \mathrm{mol} \mathrm{g}^{-1}$ and increased significantly under low temperatures. At chilling temperature, the proline content doubled, while at freezing temperature, the proline content increased 5-fold compared to the control. 


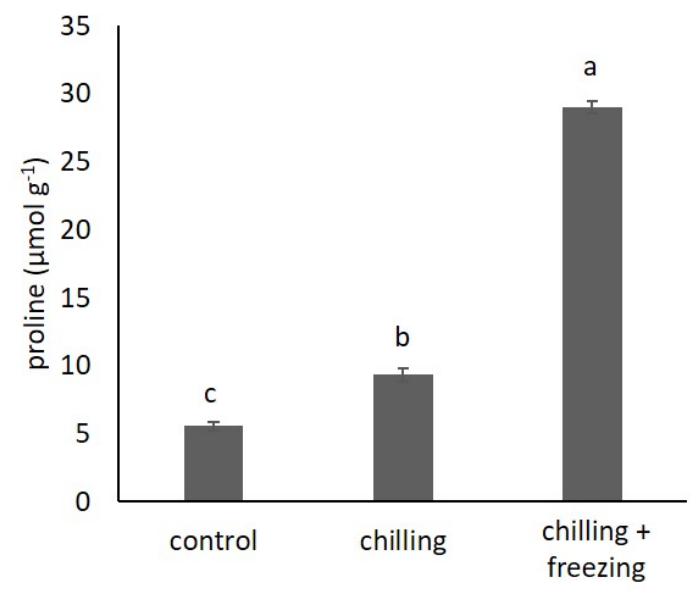

Figure 1. Proline content in Brassica oleracea var. acephala under control $\left(21^{\circ} \mathrm{C}\right)$, chilling $\left(8^{\circ} \mathrm{C}\right)$, and chilling $\left(8^{\circ} \mathrm{C}\right)+$ freezing $\left(-8{ }^{\circ} \mathrm{C}\right)$ temperatures. Value marked with different letters are significantly different at $p<0.05$.

\subsection{Contents of Chlorophylls and Carotenoids}

The content of pigments, chlorophyll $a, b$, total chlorophylls, and carotenoids in B.oleracea var. acephala under chilling and freezing temperatures is shown in Figure 2. Chilling and freezing temperatures increased the content of chlorophyll $a$ and chlorophyll $b$ but total chlorophylls content statistically did not differ. Significant increase in carotenoid contents was seen only in the samples under freezing temperature.
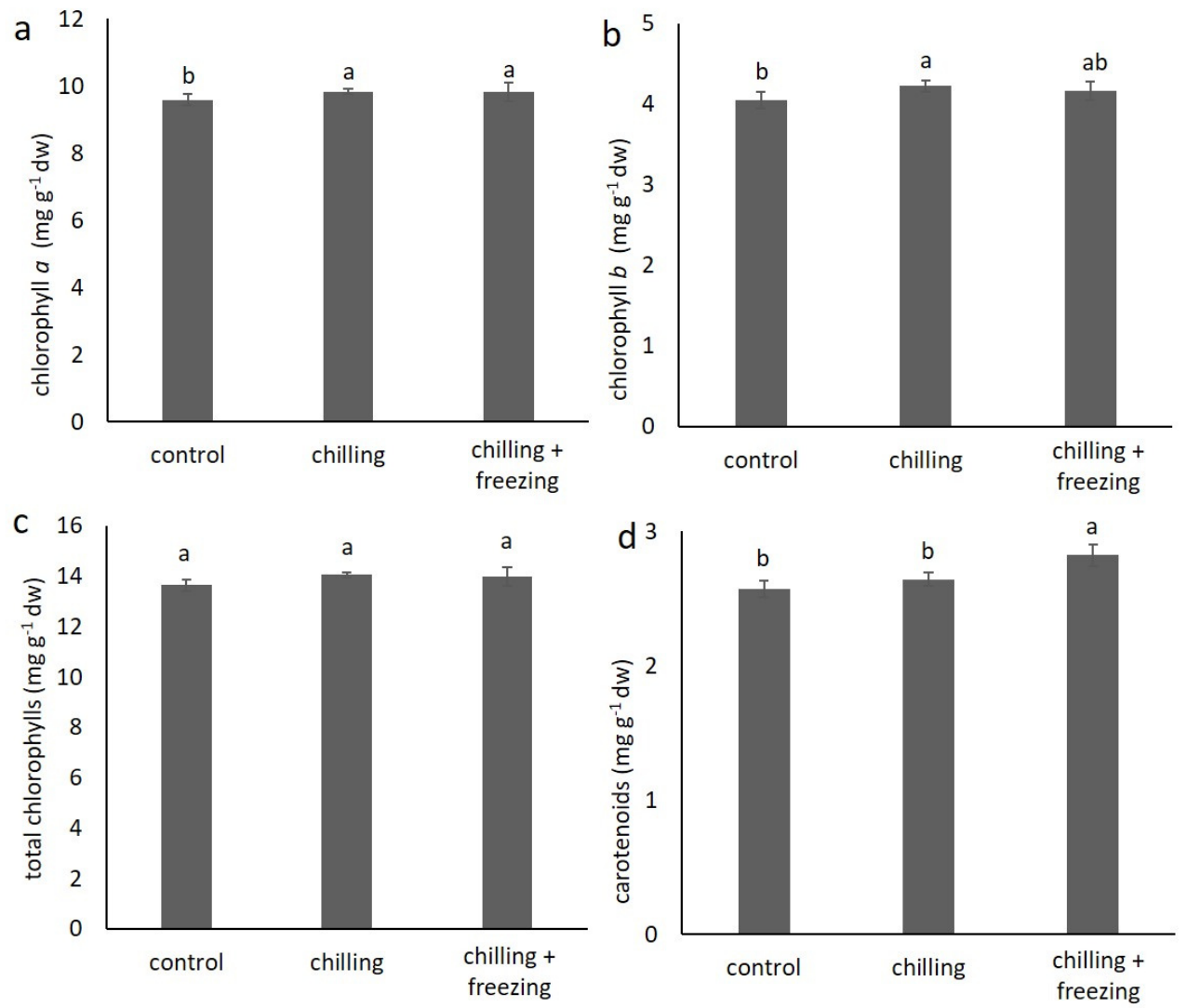

Figure 2. Content of chlorophyll $a(\mathbf{a})$, chlorophyll $b(\mathbf{b})$, total chlorophylls (c), and carotenoids (d) in Brassica oleracea var. acephala under control $\left(21^{\circ} \mathrm{C}\right)$, chilling $\left(8^{\circ} \mathrm{C}\right)$, and chilling $\left(8^{\circ} \mathrm{C}\right)+$ freezing $\left(-8^{\circ} \mathrm{C}\right)$ temperatures. Values marked with different letters are significantly different at $p<0.05$. 
The ratio of chlorophyll $a$ and chlorophyll $b$, as well as the ratio of total chlorophylls and total carotenoids, may indicate some physiological processes in plants [20]. Therefore, we also evaluated these parameters (as illustrated in Table 1). The ratio of chlorophyll $a$ to chlorophyll $b$ was just above 2 in all three groups and did not differ significantly between treatments. The ratio of total chlorophylls to total carotenoids was comparable in the control and chilling groups, while it decreased significantly under the freezing temperature.

Table 1. Ratio of chlorophyll $a$ /chlorophyll $b$ and total chlorophylls/total carotenoids in Brassica oleracea var. acephala under control $\left(21^{\circ} \mathrm{C}\right)$, chilling $\left(8^{\circ} \mathrm{C}\right)$, and chilling $\left(8^{\circ} \mathrm{C}\right)+$ freezing $\left(-8^{\circ} \mathrm{C}\right)$ temperatures. Values marked with different letters across column are significantly different at $p<0.05$.

\begin{tabular}{ccc}
\hline & $\begin{array}{c}\text { Chlorophyll } a / \\
\text { Chlorophyll } \boldsymbol{b}\end{array}$ & $\begin{array}{c}\text { Total Chlorophylls/ } \\
\text { Total Carotenoids }\end{array}$ \\
\hline control & $2.37 \pm 0.06^{\mathrm{a}}$ & $5.31 \pm 0.07^{\mathrm{a}}$ \\
chilling & $2.33 \pm 0.04^{\mathrm{a}}$ & $5.32 \pm 0.08^{\mathrm{a}}$ \\
chilling + freezing & $2.36 \pm 0.03^{\mathrm{a}}$ & $4.96 \pm 0.03^{\mathrm{b}}$ \\
\hline
\end{tabular}

\subsection{Polyphenolic Compound Contents}

The contents of total polyphenols, phenolic acids, and flavonoids under chilling and freezing temperature conditions compared to that of the control are shown in Figure 3. The total polyphenol content in the control samples was $11.61 \pm 0.33 \mathrm{mg} \mathrm{GAE} \mathrm{g}^{-1} \mathrm{dw}_{\text {; in }}$ samples under chilling temperature, it was significantly higher $\left(15.60 \pm 0.16 \mathrm{mg} \mathrm{GAE} \mathrm{g}^{-1}\right.$ $\mathrm{dw}$ ), while under freezing temperature, it was slightly lower than in that of the control $\left(10.51 \pm 0.47 \mathrm{mg} \mathrm{GAE}^{-1}\right)$. The analysis of total flavonoids and phenolic acids shows that the increase in total polyphenolics under chilling temperature could be due to the increase in total phenolic acids and flavonoids (total phenolic acids: $14.47 \pm 0.08 \mathrm{mg}$ CAE $\mathrm{g}^{-1} \mathrm{dw}$; total flavonoids: $9.04 \pm 0.10 \mathrm{mg} \mathrm{CE} \mathrm{g}^{-1} \mathrm{dw}$ ), compared to that of the control (total phenolic acids: $13.95 \pm 0.02 \mathrm{mg} \mathrm{CAE} \mathrm{g}^{-1} \mathrm{dw}$; total flavonoids: $8.55 \pm 0.14 \mathrm{mg} \mathrm{CE}$ $\left.\mathrm{g}^{-1} \mathrm{dw}\right)$. According to our results, freezing temperature led to increase in total phenolic acids and total flavonoids to $14.34 \pm 0.06 \mathrm{mg} \mathrm{CAE} \mathrm{g}^{-1} \mathrm{dw}$ and $8.87 \pm 0.17 \mathrm{mg} \mathrm{CE} \mathrm{g}^{-1} \mathrm{dw}$ respectively, but this increase was smaller than under the chilling treatment.
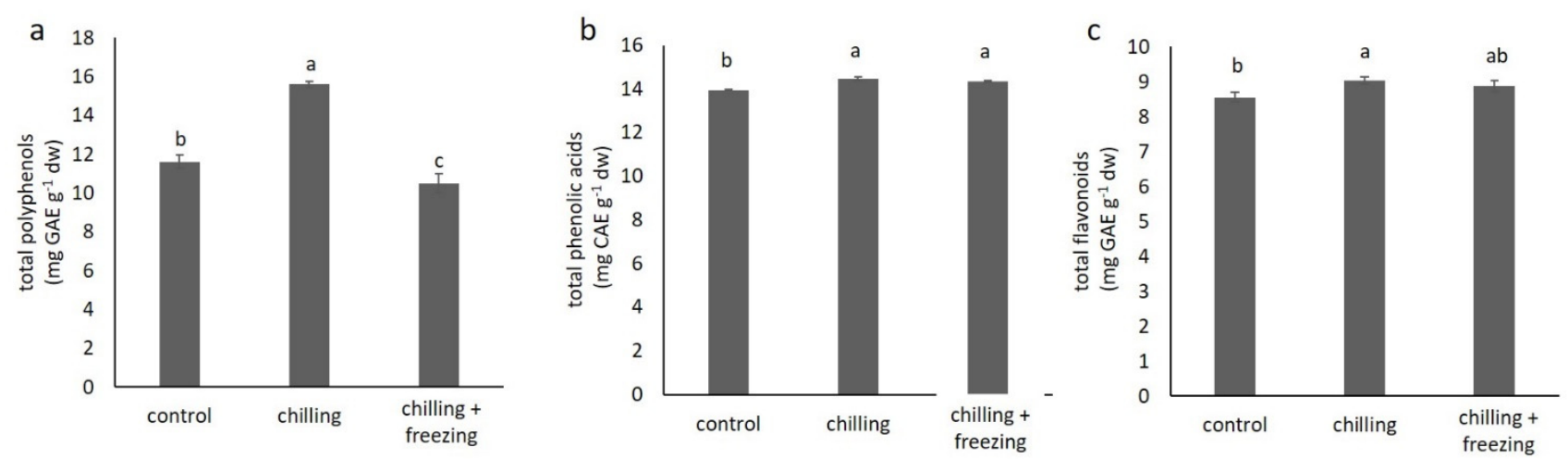

Figure 3. Total polyphenol (a), total phenolic acid (b), and total flavonoid (c) contents in Brassica oleracea var. acephala under control $\left(21^{\circ} \mathrm{C}\right)$, chilling $\left(8^{\circ} \mathrm{C}\right)$, and chilling $\left(8^{\circ} \mathrm{C}\right)+$ freezing $\left(-8{ }^{\circ} \mathrm{C}\right)$ temperatures. Values marked with different letters are significantly different at $p<0.05$.

\subsection{Glucosinolate Contents}

Glucosinolates are sulfur-containing phytochemicals found in cruciferous Brassica vegetables. In our study, we measured their content using UV/VIS spectrophotometer and HPLC-DAD. The results for total glucosinolate contents by spectrophotometric determination are shown in Figure 4. The results show a significant increase in the total 
content of glucosinolates with decreasing temperature. The total content of glucosinolates was $13.09 \pm 0.97 \mathrm{mg} \mathrm{g}^{-1} \mathrm{dw}$ in control, $17.39 \pm 0.97 \mathrm{mg} \mathrm{g}^{-1} \mathrm{dw}$ under chilling, and $25.12 \pm 1.06 \mathrm{mg} \mathrm{g}^{-1} \mathrm{dw}$ under freezing.

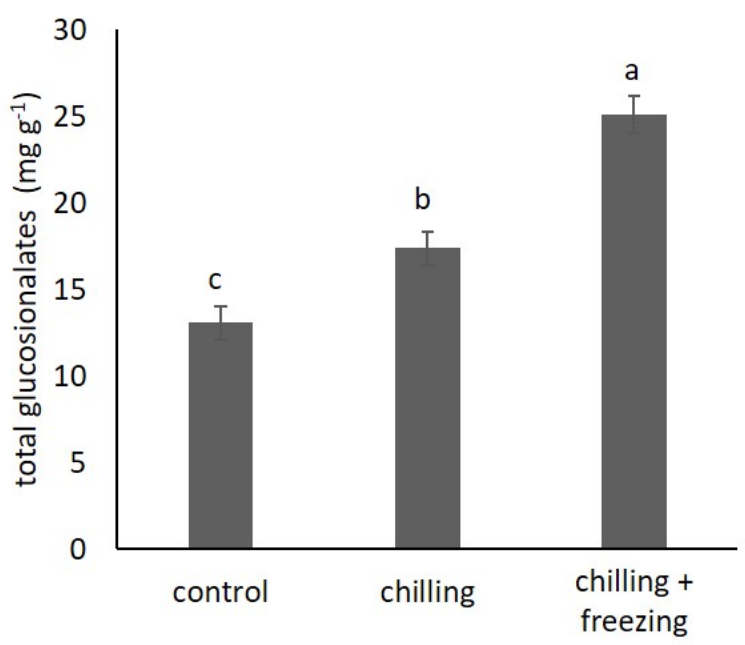

Figure 4. Spectrophotometrically measured total glucosinolate content in Brassica oleracea var. acephala under control $\left(21^{\circ} \mathrm{C}\right)$, chilling $\left(8^{\circ} \mathrm{C}\right)$, and chilling $\left(8^{\circ} \mathrm{C}\right)+$ freezing $\left(-8{ }^{\circ} \mathrm{C}\right)$ temperatures. Values marked with different letters are significantly different at $p<0.05$.

To analyze changes in individual glucosionalates in B. oleracea var. acephala under low temperature stress, we also analyzed glucosinolates by HPLC-DAD. In Figure 5, we show the content of total glucosionolates (a) and the content of total indolic (b) and aliphatic glucosinolates (c) measured by HPLC-DAD.
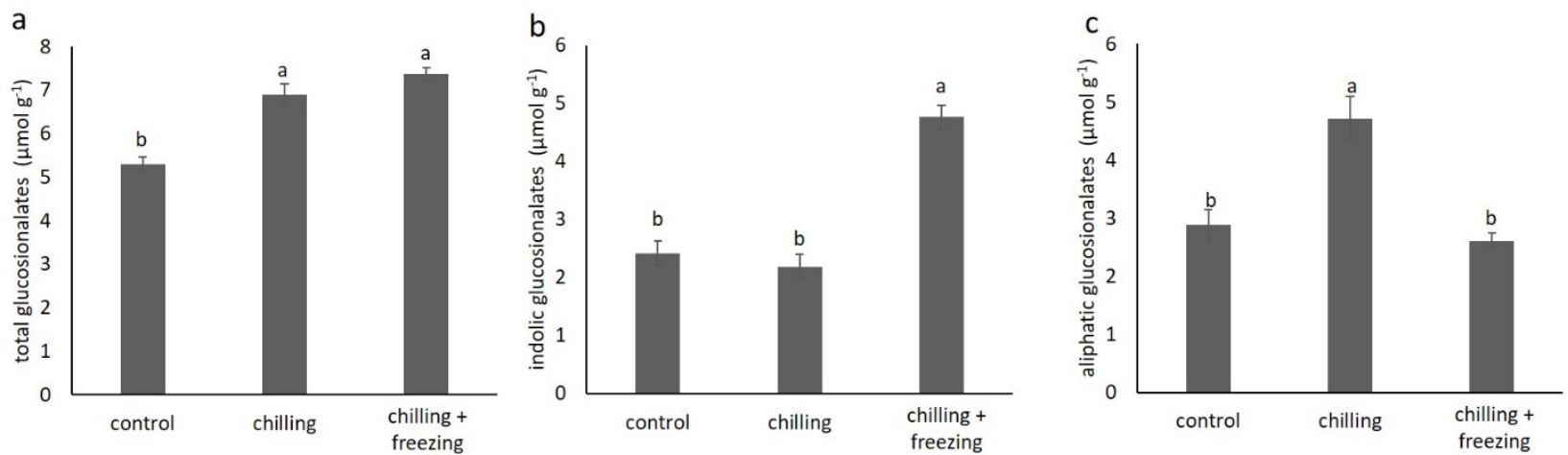

Figure 5. The content (in $\mu \mathrm{mol} \mathrm{g}{ }^{-1} \mathrm{dw}$ ) of total glucosinolates (a), indolic glucosinolates (b), and aliphatic glucosinolates (c) measured by HPLC-DAD in Brassica oleracea var. acephala under control $\left(21^{\circ} \mathrm{C}\right)$, chilling $\left(8^{\circ} \mathrm{C}\right)$ and chilling $\left(8^{\circ} \mathrm{C}\right)+$ freezing $\left(-8^{\circ} \mathrm{C}\right)$ temperatures. Values marked with different letters are significantly different at $p<0.05$.

As can be seen from Figure 5, the HPLC-DAD measurement was in agreement with the spectrophotometric data showing that low temperature treatments increased the content of glucosinolates. However, the increase in the total content of glucosionaltes under freezing temperature as measured by HPLC-DAD was lower than what was measured spectrophotometrically. The HPLC-DAD measurement also showed that chilling temperature increased aliphatic glucosinolates while freezing temperature increased indolic glucosinolates. The content of individual glucosionolates is shown in Table 2. 
Table 2. The content of individual glucosinolates $\left(\mu \mathrm{mol} \mathrm{g}{ }^{-1} \mathrm{dw}\right)$ measured by HPLC-DAD in Brassica oleracea var. acephala under control $\left(21^{\circ} \mathrm{C}\right)$, chilling $\left(8^{\circ} \mathrm{C}\right)$, and chilling $\left(8^{\circ} \mathrm{C}\right)+$ freezing $\left(-8{ }^{\circ} \mathrm{C}\right)$ temperatures. Values marked with different letters across rows are significantly different at $p<0.05$.

\begin{tabular}{|c|c|c|c|c|}
\hline & & Control & Chilling & Chilling + Freezing \\
\hline \multirow{5}{*}{ aliphatic } & Glucoiberin & $1.87 \pm 0.02^{b}$ & $2.75 \pm 0.18^{a}$ & $1.13 \pm 0.16^{b}$ \\
\hline & Progoitrin & $0.19 \pm 0.06^{b}$ & $0.32 \pm 0.04^{\mathrm{a}}$ & nd \\
\hline & Sinigrin & $0.57 \pm 0.06^{\mathrm{c}}$ & $0.82 \pm 0.12^{b}$ & $1.18 \pm 0.10^{\mathrm{a}}$ \\
\hline & Glucoraphanin & $0.25 \pm 0.01^{\mathrm{c}}$ & $0.85 \pm 0.06^{\mathrm{a}}$ & $0.41 \pm 0.05^{b}$ \\
\hline & Gluconapin & nd & nd & nd \\
\hline \multirow{4}{*}{ indolic } & 4-hydroxyglucobrassicin & $0.18 \pm 0.02^{a}$ & $0.20 \pm 0.05^{\mathrm{a}}$ & $0.15 \pm 0.01^{\mathrm{a}}$ \\
\hline & Glucobrassicin & $2.05 \pm 0.36^{b}$ & $1.86 \pm 0.16^{\mathrm{b}}$ & $3.98 \pm 0.18^{a}$ \\
\hline & 4-methoxyglucobrassicin & $0.10 \pm 0.01^{\mathrm{a}}$ & $0.05 \pm 0.02^{\mathrm{a}}$ & $0.07 \pm 0.06^{\mathrm{a}}$ \\
\hline & Neoglucobrasscin & $0.09 \pm 0.03^{b}$ & $0.04 \pm 0.01^{\mathrm{c}}$ & $0.14 \pm 0.02^{\mathrm{a}}$ \\
\hline
\end{tabular}

In the control plants, indolic glucosionolate glucobrassicin was the most abundant glucosinolate species measured. Its content nearly doubled, while the content of the less abundant neoglucobrassicin also increased under the freezing treatment. These compounds probably contribute to the significant increase in indolic glucosionolates under the freezing conditions (as illustrated in Figure 5b). Glucobrassicin and 4-methoxyglucobrassicin content did not change under chilling or freezing treatment.

The most abundant aliphatic glucosionolate in the control samples was glucoiberin which increased by $50 \%$ under chilling temperature, but its content in the samples at freezing temperature was comparable to that of the corresponding control. The content of progoitrin and glucoraphanin was also increased significantly after chilling. For sinigrin, there is a clear trend of increase by lowering the temperature. It was increased 1.5-fold and 1.9-fold after chilling and freezing, respectively.

\section{Discussion}

Specialized metabolites play important roles in plant-environmental interactions, although their specific roles in plants are still not clear. Therefore, in our study we sought to determine the levels of bioactive compounds in B. oleracea var. acephala under low temperature stress to narrow down the individual species that may be involved in the interaction.

First, we determined the content of proline, which is a well-known stress marker [21]. Proline can act as an osmolyte, but it is also known for its role as a metal chelator, an antioxidant defense molecule, and a signaling molecule [21]. Thus, it is not surprising that we found a significant increase in proline content under chilling ( 1.7 -fold) and freezing (5.2-fold) conditions compared to that of the control. A similar trend of increase in proline contents at low temperatures was previously reported for B. oleracea var. acephala [22] and rapeseed (Brassica napus L.) [23,24].

Stressful conditions can reduce photosynthetic ability of plants because photosynthesis is an integrated and tightly regulated process that is very sensitive to any change in environmental conditions [25]. Low temperatures reportedly affect chlorophyll levels in plant species depending on their cold tolerance $[25,26]$. Plants with good cold tolerance maintain stable chlorophyll content, while plants with low cold tolerance experience a decrease in chlorophyll content [26]. Atici et al. [22] reported a decrease in chlorophyll content compared to that of the control in B. oleracea var acephala during acclimation to low temperatures in the first 15 days of exposure, while after 45 days, chlorophyll content was higher in plants grown under cold conditions than in that of the control. This might indicate adaptation of photosynthetic apparatuses to cold temperature. In our study, small changes in chlorophyll and carotenoid contents are consistent with the fact that B. oleracea var acephala is a plant with good cold tolerance. Moreover, the ratio of total chlorophyll/total 
carotenoids is an indicator of damage to the plant and the photosynthetic apparatus. Values below 4.2 are indicative of senescence, stress, and more rapid degradation of chlorophylls than carotenoids [27]. Although in our experiments values are not lower than 4.2, freezing temperature decreases this parameter, which may indicate reduced activity but not yet damage to the photosynthetic apparatus.

Polyphenols are a large group of specialized metabolites that play different roles in plant-environmental interactions (reviewed by Šamec et al. [8]). According to our results (as illustrated in Figure 3), chilling temperature significantly increases total polyphenol content, while freezing temperature decreases total polyphenol content compared to that of the control. According to the literature [1], polyphenolic compounds in B. oleracea var. acephala belong mainly to phenolic acids and flavonoids, which we measured in our experiment (as illustrated in Figure 3b,c). We found an increase in the content of phenolic acids and flavonoids under chilling and freezing temperatures, indicating the involvement of these compounds in stress tolerance at low temperatures. This is consistent with literature data for several Brassica species where authors reported an increase in flavonoids and/or phenolic acids under low temperatures [15,28]. Sharma et al. [29] summarized that low temperature stress in plants increases the expression of phenylpropanoid pathway enzymes such as PAL (phenylalanine ammonia lyase), CAD (cinnamylalcohol dehydrogenase), and HCT (hydroxycinnamoyl transferase) and consequently increases phenolic content. Increased phenolic levels further contribute to detoxification of ROS and accumulation of polyphenolic compounds in plant cell walls and increase cell wall thickness [8]. This process is beneficial for the prevention of chilling damage and cell collapse under cold stress [29].

Glucosinolates are a large group of specialized metabolites present in Brassica species. There is a growing body of scientific evidence showing that they are an important factor in abiotic stress responses [7,17]. Our spectrophotometric data showed significant increase in glucosinolate contents at lower temperatures (as illustrated in Figure 5). An interesting trend is observed for total indolic and aliphatic glucosinolates calculated based on HPLC-DAD analysis. Our data showed that chilling temperature increased aliphatic glucosinolates, while freezing temperature increased indolic glucosinolates. In contrast, Sarıkamış and Çakır [30] reported that low temperature $\left(0^{\circ} \mathrm{C}\right)$ significantly decreased both aliphatic and indolic glucosinolates in broccoli (Brassica oleracea var. italic L.), and they concluded that this was due to hydrolysis and degradation of glucosinolates during cell disruption, which could be the result of low temperature treatments. Similarly, Steindal et al. [18] reported that cold acclimation of B. oleracea var acephala generally resulted in some reduction in the content of total and individual glucosinolates. They reported that the most abundant glucosinolate in B. oleracea var acephala is glucobrassicin, which is consistent with our data. Each cruciferous species/variety shows a characteristic glucosinolate profile that includes more than ten different glucosinolates, although only 3-4 are typically predominant [31]. Glucobrassicin is reported as the predominant glucosinolate in B. oleracea var. acephala in several other studies [32,33]. According to our data, glucobrassicin content remains stable at chilling temperature but nearly doubles at freezing temperature. We found that the most abundant aliphatic glucosinolate in the control plants was glucoiberin, whose content increased under chilling temperature, while under freezing temperature it was comparable to that of the control plants. Only sinigrin showed a clear trend of increasing content with decreasing temperature. Our data suggest that glucosinolates are involved in low temperature stress, but also that individual glucosinolates show a different trend under chilling and freezing temperature. A similar trend was reported for broccoli [30]. We speculate that this is because different glucosinolate species are involved in different protective mechanisms due to different chemical structures and bioactivities. 


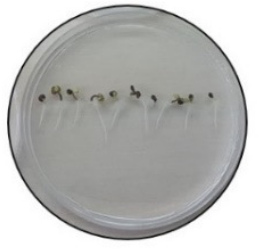

Seed sterilization and agar germination of seedlings

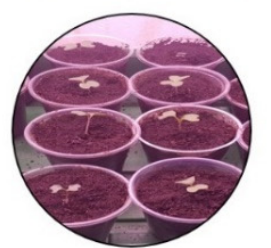

Seedling transfering to supstrat

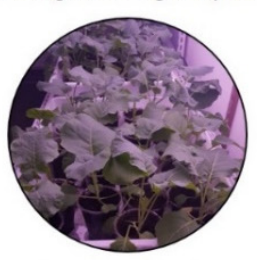

Growing for 9 weeks

\section{Materials and Methods}

\subsection{Plant Growth and Low Temperature Treatment}

Seeds were purchased from family farm Srđan Franić from Vrgorac, Croatia. Seed sterilization and germination were described previously [34]. Germinated seedlings were placed in a commercial substrate Stender A240 (Schermbeck, Germany) for plant growth and grown under controlled environmental conditions at a temperature of $21^{\circ} \mathrm{C}$ and $16 / 8 \mathrm{~h}$ photoperiod (light/dark). After 4 weeks, all plants were repotted into larger pots with new substrate to ensure sufficient plant nutrients throughout the experiments. Each individual plant grew in a separate pot and was watered regulary. When the plants were 9 weeks old, 10 plants remained in a chamber at $21^{\circ} \mathrm{C}$ serving as the control while 20 plants were transfered to a chamber where the temperature was set at $8{ }^{\circ} \mathrm{C}$ and remained there for 7 days under identical conditions of photoperiod and light intensity to the first group. Exactly after 6 days and $23 \mathrm{~h}$ at $8{ }^{\circ} \mathrm{C}, 10$ plants were exposed furthermore to freezing temperature at the chamber set at $-8^{\circ} \mathrm{C}$ for one hour. Plants from all three temperature regimes were harvested at the same time, frozen in liquid nitrogen, and stored at $-80^{\circ} \mathrm{C}$. All samples were then freeze-dried at the same time in Lyovac GT 2 (Steris GmbH, Köln, Germany). The freeze-dried samples were used for further extraction and analysis. The sheme of the low temperature experiments is shown in Figure 6.

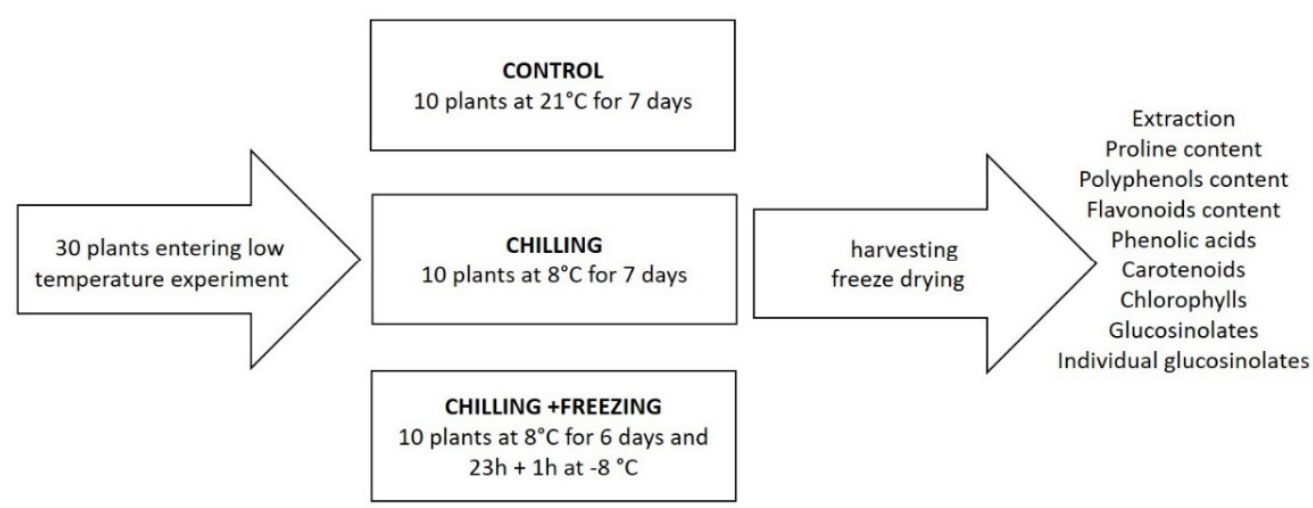

Figure 6. Scheme of the low temperature stress experiments.

\subsection{Determination of Proline Content}

Proline content was determined using 1\% ninhydrin as we reported earlier [10]. For extraction, we used $30 \mathrm{mg}$ of the freeze-dried tissue and $70 \%$ ethanol. Then, $100 \mu \mathrm{L}$ of the obtained extract were mixed with $1 \mathrm{~mL}$ of reaction mixture containing $1 \%$ ninhydrin, $60 \%$ acetic acid, and $20 \%$ ethanol. Mixtures were heated at $95{ }^{\circ} \mathrm{C}$ for $20 \mathrm{~min}$, cooled, and proline levels were measured at $520 \mathrm{~nm}$ using a UV-VIS spectrophotometer (Shimadzu BioSpec-1601, Kyoto, Japan). For the calibration curve proline standard (Sigma-Aldrich, Saint Louis, MO, USA) was used $\left(0-1.6 \mathrm{mM}, \mathrm{y}=1.4331 \mathrm{x}, \mathrm{R}^{2}=0.999\right)$ and results are expressed as $\mu \mathrm{mol} \mathrm{g}^{-1} \mathrm{dw}$. 


\subsection{Determination of Total Phenol Content}

For the determination of total phenols, we prepared an extract from $60 \mathrm{mg}$ of dry samples and $2 \mathrm{~mL}$ of $80 \%$ methanol and determined total phenols using Folin-Ciocalteu reagent, as previously reported [35]. For the calibration curve, we used gallic acid (SigmaAldrich, USA) $\left(0-1 \mathrm{~g} / \mathrm{mL}, \mathrm{y}=0.001 \mathrm{x}, \mathrm{R}^{2}=0.999\right)$ and the results are expressed as gallic

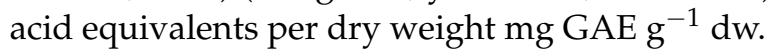

\subsection{Determination of Total Phenolic Acids}

Total phenolic acids were determined using Arnow's reagent (10 g sodium nitrite, $10 \mathrm{~g}$ sodium molybdate, and distilled water up to $100 \mathrm{~mL}$ ) [36]. The method was adopted for a small volume as follows. In brief, $300 \mu \mathrm{L}$ of distillated water, $300 \mu \mathrm{L}$ of the plant extract, $100 \mu \mathrm{L}$ of Arnow's reagent and $100 \mu \mathrm{L}$ of $0.5 \mathrm{M}$ hydrochloric acid per sample were mixed together. Next, $100 \mu \mathrm{L}$ of $1 \mathrm{M}$ sodium hydroxide and $100 \mu \mathrm{L}$ of distilled water were added. Mixure were centrifugeted and absorbance was measured at $490 \mathrm{~nm}$. Caffeic acid (Sigma-Aldrich, USA) served as a standard for the construction of the calibrattion curve and the results were expresed as caffeic acid equivalents per dry weight (mg CAE g $\left.{ }^{-1} \mathrm{dw}\right)$.

\subsection{Determination of Total Flavonoids}

Total flavonoids were determined using the method with $\mathrm{Al}_{2} \mathrm{Cl}_{3}$ according to Zhinshen et al. [37], which we previously optimized for Brassica samples [35]. For the calibration curve, we used catechin (Sigma-Aldrich, USA) and results are expressed as catechin equivalents per dry weight ( $\left.\mathrm{mg} \mathrm{CE} \mathrm{g}^{-1} \mathrm{dw}\right)$.

\subsection{Determination of Chlorophyll and Carotenoid Contents}

Contents of chlorophyll $a$, chlorophyll $b$ and carotenoids were determined spectrophotometrically according Lichtenthaler et al. [20] in samples extracted with $80 \%$ acetone. Results were expresses as $\mu \mathrm{g} \mathrm{g}^{-1} \mathrm{dw}$.

\subsection{Determination of Total and Individual Glucosinolates}

For spectrophotometric determination, we used the method reported by Aghajanzaden et al. [38] and optimized for kale samples [35]. For the calibration curve, we used sinigrin (Carl Roth, Karlsruhe, Germany) and the results were expressed as milligrams of

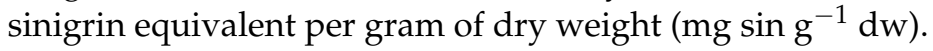

Individual glucosinolates were determined and quantfied by HPLC-DAD using the optimized ISO method 10633-1 (1995) as we previously reported [39]. Results are expressed as $\mu \mathrm{mol} \mathrm{g}{ }^{-1} \mathrm{dw}$ (dry weight).

\subsection{Statistical Analysis}

All analyses were performed in at least three replicates and results are expressed as a mean \pm standard deviation (SD). All statistical analyses were performed using Microsoft Office Excel 2010 upgraded with XLSTAT (ver. 1 May 2011). One-way ANOVA and post hoc multiple mean comparison (Tukey's HSD test) were performed and differences between measurements were considered significant at $p<0.05$.

\section{Conclusions}

In our study, we determined the content of proline, chlorophylls, carotenoids, polyphenols, and glucosinolates in B. oleracea var. acephala plants subjected to chilling and freezing temperature stress under controlled laboratory conditions. Chilling and freezing significantly increase proline contents, confirming the stress status of the treated plants. Low temperature also causes the increase in the contents of chlorophylls, phenolic acids, flavonoids, and glucosinolates. Analysis of individual glucosinolates showed that chilling temperature increased aliphatic glucosinolates, while freezing temperature increased indolic glucosinolates. The most abundant glucosinolate was glucobrassicin, which increased significantly under freezing temperature. Our data suggest that glucosinolates play a role 
in low temperature stress, but that individual glucosinolates show different accumulation trends under chilling and freezing conditions. Further studies are needed that directly link the chemical structure of glucosinolates to their response to cold stress.

Author Contributions: Conceptualization, D.Š.; methodology, D.Š. and V.L.; investigation, V.L., D.Š., I.R.R., A.S., S.R. and B.S.-S.; data curation, D.Š.; writing—original draft preparation, D.Š.; writingreview and editing, D.Š., V.L., A.S., B.S.-S., S.R. and I.R.R.; visualization, D.Š.; supervision, D.Š., I.R.R., B.S.-S. and S.R.; project administration, D.Š. and S.R.; funding acquisition, D.Š. and S.R. All authors have read and agreed to the published version of the manuscript.

Funding: This research was funded by Unity through Knowledge Fund, grant number 12/17, and by the Operational Programme Competitiveness and Cohesion 2014-2020 and the Croatian European regional fund under a specific scheme to strengthen applied research in proposing actions for climate change adaptation (Project No. KK.05.1.1.02.0005).

Data Availability Statement: Additional data are available upon request.

Acknowledgments: We thank OPG Srđan Franić for providing the seeds used in the experiment.

Conflicts of Interest: The authors declare no conflict of interest.

\section{References}

1. Šamec, D.; Urlić, B.; Salopek-Sondi, B. Kale (Brassica oleracea var. acephala) as a superfood: Review of the scientific evidence behind the statement. Crit. Rev. Food Sci. Nutr. 2019, 59, 2411-2422. [CrossRef]

2. Šamec, D.; Salopek-Sondi, B. Cruciferous (Brassicaceae) vegetables. In Nonvitamin and Nonmineral Nutritional Supplements; Nabavi, S.M., Sanches Silva, T., Eds.; Academic Press: Cambridge, MA, USA, 2019; pp. 195-202.

3. Quirante-Moya, S.; García-Ibañez, P.; Quirante-Moya, F.; Villaño, D.; Moreno, D.A. The Role of Brassica Bioactives on Human Health: Are We Studying It the Right Way? Molecules 2020, 25, 1591. [CrossRef]

4. Favela-González, K.M.; Hernández-Almanza, A.Y.; Fuente-Salcido, N.M. The value of bioactive compounds of cruciferous vegetables (Brassica) as antimicrobials and antioxidants: A review. J. Food Biochem. 2020, 44, e13414. [CrossRef]

5. Šamec, D.; Linić, I.; Salopek-Sondi, B. Salinity Stress as an Elicitor for Phytochemicals and Minerals Accumulation in Selected Leafy Vegetables of Brassicaceae. Agronomy 2021, 11, 361. [CrossRef]

6. Renna, M.; Stellacci, A.M.; Corbo, F.; Santamaria, P. The Use of a Nutrient Quality Score is Eective to Assess the Overall Nutritional Value of Three Brassica Microgreens. Foods 2020, 9, 1226. [CrossRef] [PubMed]

7. Essoh, A.P.; Monteiro, F.; Pena, A.R.; Pais, M.S.; Moura, M.; Romeiras, M.M. Exploring glucosinolates diversity in Brassicaceae: A genomic and chemical assessment for deciphering abiotic stress tolerance. Plant Physiol. Biochem. 2020, 150, 151-161. [CrossRef] [PubMed]

8. Šamec, D.; Karalija, E.; Šola, I.; Vujčić-Bok, V.; Salopek-Sondi, B. The Role of Polyphenols in Abiotic Stress Response: The Influence of Molecular Structure. Plants 2021, 10, 118. [CrossRef]

9. Pavlović, I.; Petrík, I.; Tarkowska, D.; Lepeduš, H.; Vujčić Bok, V.; Radić Brkanac, S.; Novák, O.; Salopek Sondi, B. Correlations between Phytohormones and Drought Tolerance in Selected Brassica Crops: Chinese Cabbage, White Cabbage and Kale. Int. J. Mol. Sci. 2018, 19, 2866. [CrossRef]

10. Linić, I.; Šamec, D.; Grúz, J.; Vujčić, B.V.; Strnad, M.; Salopek Sondi, B. Involvement of Phenolic Acids in Short-Term Adaptation to Salinity Stress is Species-Specific among Brassicaceae. Plants 2019, 8, 155. [CrossRef]

11. Pavlović, I.; Mlinarić, S.; Tarkowska, D.; Oklestkova, J.; Novak, O.; Lepeduš, H.; Vujčić Bok, V.; Radić Brkanac, S.; Strnad, M.; Salopek Sondi, B. Early Brassica crops responses to salinity stress: A Comparative Analysis between Chinese cabbage, White cabbage and Kale. Front. Plant Sci. 2019, 10, 450. [CrossRef]

12. Soengas, P.; Rodríguez, V.M.; Velasco, P.; Cartea, M.E. Effect of Temperature Stress on Antioxidant Defenses in Brassica oleracea. ACS Omega 2018, 3, 5237-5243. [CrossRef]

13. Podda, A.; Pollastri, S.; Bartolini, P.; Pisuttu, C.; Pellegrini, E.; Nali, C.; Cencetti, G.; Michelozzi, M.; Frassinetti, S.; Giorgetti, L.; et al. Drought stress modulates secondary metabolites in Brassica oleracea L. convar. acephala (DC) Alef, var. sabellica L. J. Sci. Food Agric. 2019, 99, 5533-5540. [CrossRef] [PubMed]

14. Ahmed, N.U.; Park, J.-I.; Jung, H.-J.; Hur, Y.; Nou, I.-S. Anthocyanin biosynthesis for cold and freezing stress tolerance and desirable color in Brassica rapa. Funct. Integr. Genom. 2015, 15, 383-394. [CrossRef] [PubMed]

15. Neugart, S.; Krumbein, A.; Zrenner, R. Influence of Light and Temperature on Gene Expression Leading to Accumulation of Specific Flavonol Glycosides and Hydroxycinnamic Acid Derivatives in Kale (Brassica oleracea var. sabellica). Front. Plant Sci. 2016, 7, 326. [CrossRef] [PubMed]

16. Mageney, V.; Baldermann, S.; Albach, D.C. Intraspecific Variation in Carotenoids of Brassica oleracea var. sabellica. J. Agric. Food Chem. 2016, 64, 3251-3257.

17. Martínez-Ballesta, M.C.; Moreno, D.A.; Carvajal, M. The Physiological Importance of Glucosinolates on Plant Response to Abiotic Stress in Brassica. Int. J. Mol. Sci. 2013, 14, 11607-11625. [CrossRef] 
18. Steindal, A.L.H.; Rødven, R.; Hansen, E.; Mølmann, J. Effects of photoperiod, growth temperature and cold acclimatisation on glucosinolates, sugars and fatty acids in kale. Food Chem. 2015, 174, 44-51. [CrossRef]

19. Jurkow, R.; Wurst, A.; Kalisz, A.; Agnieszka Sękara, A.; Cebula, S. Cold stress modifies bioactive compounds of kale cultivars during fall-winter harvests. Acta Agrobot. 2019, 72, 1761. [CrossRef]

20. Lichtenthaler, H.K.; Buschmann, C. Chlorophylls and carotenoids: Measurement and characterization by UV-VIS spectroscopy. In Current Protocols in Food Analytical Chemistry; John Wiley \& Sons, Inc.: Hoboken, NJ, USA, 2001; pp. F4.3.1-F4.3.8.

21. Hayat, S.; Hayat, Q.; Alyemeni, M.N.; Wani, A.S.; Pichtel, J.; Ahmad, A. Role of proline under changing environments. Plant Signal. Behav. 2012, 7, 1456-1466. [CrossRef] [PubMed]

22. Atici, O.; Demir, Y.; Kocaçalikan, I. Effects of Low Temperature on Winter Wheat and Cabbage Leaves. Biol Plant. 2003, 46, 603-606. [CrossRef]

23. He, H.; Lei, Y.; Yi, Z.; Raza, A.; Zeng, L.; Yan, L.; Xiaoyu, D.; Yong, C.; Xiling, Z. Study on the mechanism of exogenous serotonin improving cold tolerance of rapeseed (Brassica napus L.) seedlings. Plant Growth Regul. 2021, 94, 161-170. [CrossRef]

24. Zhang, J.; Jiang, F.; Yang, P.; Li, J.; Yan, G.; Hu, L. Responses of canola (Brassica napus L.) cultivars under contrasting temperature regimes during early seedling growth stage as revealed by multiple physiological criteria. Acta Physiol Plant. 2015, 37, 7. [CrossRef]

25. Ensminger, I.; Busch, F.; Huner, N.P.A. Photostasis and cold acclimation: Sensing low temperature through photosynthesis. Phisiol. Plant. 2006, 126, 28-44. [CrossRef]

26. Kalaji, H.M.; Jajoo, A.; Oukarroum, A.; Brestic, M.; Zivcak, M.; Samborska, I.A.; Cetner, M.D.; Łukasik, I.; Goltsev, V.; Ladle, R.J. Chlorophyll a fluorescence as a tool to monitor physiological status of plants under abiotic stress conditions. Acta Physiol Plant. 2016, 38, 102. [CrossRef]

27. Zietz, M.; Weckmüller, A.; Schmidt, S.; Rohn, S.; Schreiner, M.; Krumbein, A.; Kroh, L.W. Genotypic and climatic influence on the antioxidant activity of flavonoids in Kale (Brassica oleracea var. sabellica). J. Agric. Food Chem. 2010, 58, 2123-2130. [CrossRef]

28. Sharma, A.; Shahzad, B.; Rehman, A.; Bhardwaj, R.; Landi, M.; Zheng, B. Response of Phenylpropanoid pathway and the role of Polyphenols in Plants under Abiotic Stress. Molecules 2019, 24, 2452. [CrossRef]

29. Sarıkamış, G.; Çakır, A. Influence of low temperature on aliphatic and indole glucosinolates in broccoli (Brassica oleracea var. italica L.). Acta Hortic. 2016, 1145, 79-84. [CrossRef]

30. Fahey, J.W.; Stephenson, K.K.; Wade, K.L.; Talalay, P. Urease from Helicobacter pylori is inactivated by sulforaphane and other isothiocyanates. Biochem. Biophys. Res. Commun. 2013, 435, 1-7. [CrossRef] [PubMed]

31. Kapusta-Duch, J.; Kusznirewic, B.; Leszczynska, T.; Borczak, B. Effect of conventional cooking on changes in the contents of basic composition and glucosinolates in kale. Ecol. Chem. Eng. A 2016, 23, 465-480.

32. Korus, A.; Slupski, J.; Gebczynski, P.; Bana, A. Effect of preliminary processing and method of preservation on the content of glucosinolates in kale (Brassica oleracea L. var. acephala) leaves. LWT Food Sci. Technol. 2014, 59, 1003-1008. [CrossRef]

33. Cartea, M.E.; Velasco, P.; Obregon, S.; Padilla, G.; de Haro, A. Seasonal variation in glucosinolate content in Brassica oleracea crops grown in northwestern Spain. Phytochemistry 2008, 69, 403-410. [CrossRef] [PubMed]

34. Šamec, D.; Kruk, V.; Ivanišević, P. Influence of Seed Origin on Morphological Characteristics and Phytochemicals Levels in Brassica oleracea var. acephala. Agronomy 2019, 9, 502. [CrossRef]

35. Šamec, D.; Bogović, M.; Vincek, D.; Martinčić, J.; Salopek-Sondi, B. Assessing the authenticity of the white cabbage (Brassica oleracea var. capitata f. alba) cv. 'Varaždinski' by molecular and phytochemical markers. Food Res. Int. 2014, 60, 266-272. [CrossRef]

36. McMath, A. European Pharmacopoeia, 4th ed.; Council of Europe: Strasbourg, France, 2004; pp. 2377-2378.

37. Zhishen, J.; Mengcheng, T.; Jianming, W. The determination of flavonoid contents inmulberry and their scavenging effects on superoxide radicals. Food Chem. 1999, 64, 555-559. [CrossRef]

38. Aghajanzadeh, T.A.; Hawkesford, M.J.; De Kok, L.J. The significance of glucosinolates for sulfur storage in Brassicaceae seedlings. Front. Plant Sci. 2014, 5, 704. [CrossRef]

39. Jakovljević, T.; Cvjetko, M.; Sedak, M.; Đokić, M.; Bilandžić, N.; Vorkapić-Furač, J.; Radojčić-Redovniković, I. Balance of glucosinolates content under Cd stress n two Brassica species. Plant Physiol. Biochem. 2013, 63, 99-106. [CrossRef] [PubMed] 